\title{
SEJARAH RELIGIO-POLITIK DI SINGAPURA Interaksi Islam dalam Dinamika Politik Multi Etnis
}

\author{
Oleh: Mustofa Umar*
}

Abstract

In this article, the writer tries to explain the historicity of political system formulation and government in Singapore. Besides, the writer also explores the religion role in establishing state institution. Moreover, the writer specifies that social structure of Singapore society -the multi racial country with the majority of Chinese immigranthave been working out nationalism awareness. The political social interaction based on ethnic and religious sentiment had crystallized and ended by separation of Singapore from Malaysia federation, as a free country based on industry and trade. In many sectors, the sake of Singaporean Moslems is accommodated. The accommodated Moslems' aspiration is along with the improvement of Moslems awareness of the important of formal institution to accommodate their aspiration. However, Islam is still paced as a distrustful movement.

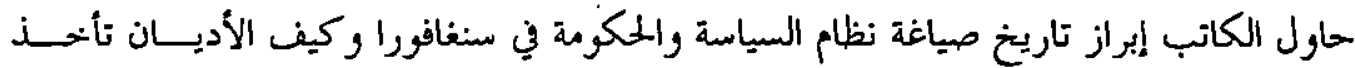

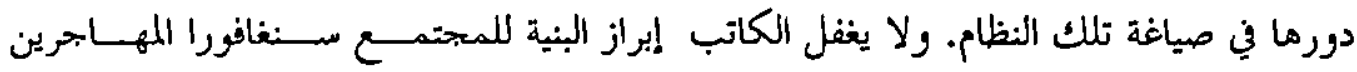

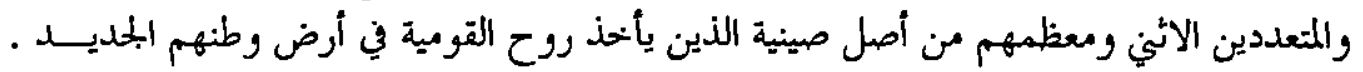

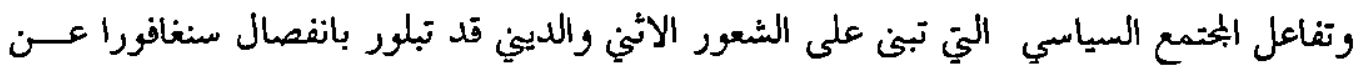

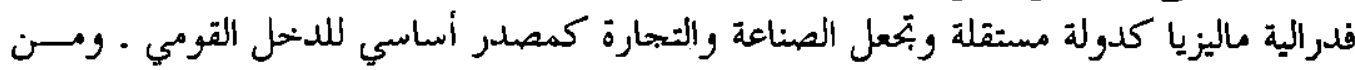

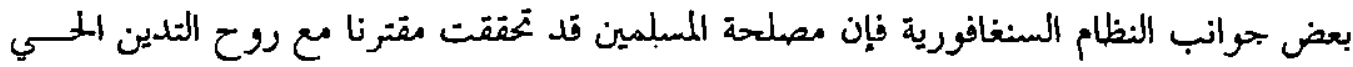

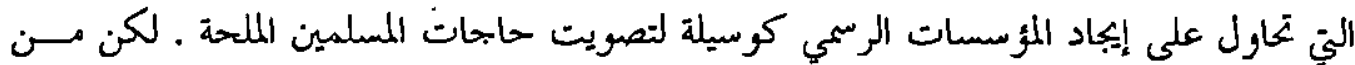

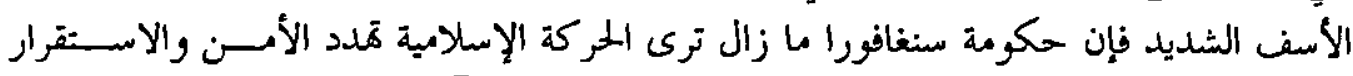

Kata Kunci: Religio-Politik, Singapura, Politik Multi Etnis 


\section{A. Pendahuluan}

i kawasan Asia Tenggara, Singapura memiliki perjalanan sejarah yang unik, ' dengan struktur sosial yang telah kehilangan identitas budaya asli setempat akibat penetrasi dari berbagai budaya asing yang pernah menguasainya. Meskipun sebagai salah satu negara terkecil di dunia, namun Singapura memiliki populasi dengan komposisi yang sangat plural dengan mayoritas penduduk imigran Cina, sebagian Arab, India dan penduduk Melayu. Pluralitas agama, etnis dan budaya merupakan tantangan paling besar dalam menciptakan sebuah tatanan negara dengan satu identitas nasional. ${ }^{2}$ Karakter sosial yang plural tersebut, akomodasi politik terhadap kepentingan agama diwarnai dengan tekanan-tekanan oleh para aktivis agama. ${ }^{3}$ Akan tetapi Singapura dengan pengalaman perjalanan sejarahnya, telah membuktikan sebagai sebuah negara modern yang mampu melintasi perbedaan etnis dan agama. Bagaimana formulasi sistem politik dan pemerintahan Singapura dan sejauh mana peran agama dalam pembentukan institusi negara, akan menjadi pembahasan dalam artikel berikut.

\section{B. Struktur Sosial Singapura}

Sejarah Singapura tidak lepas dari perjalanan sejarah Melayu, catatan sejarah awal Melayu sangat bervariasi dengan berbagai versi dan nuansa yang bermacam-macam

'Sejarah Singapura merupakan bagian dari sejarah Malaysia. Upaya awal untuk menghimpun sejarah Singapura mengalami sedikit perkembangan dan kemajuan melalui manuskripmanuskrip yang dimiliki oleh Reffles sampai dia tewas terhempas ombak pada kecelakaan laut pada tahun 1824. Thomas Braddell melanjutkan usaha ini, namun yang terpublikasikan hanya koleksi dari dokumen-dokumen mengenai beberapa catatan tentang Singapura yang dimuat dalam Jurnal of Indian Archipelago pada tahun 1850. Singapura baru mendapat pelayanan sipil pada tahun 1954 atau delapan tahun setelah mendapat pengakuan resmi sebagai bagian dari koloni tersendiri. Hal itu hanya sebatas selingan dan sebagai pelarian dari tantangan dan tugas-tugas negara yang aneh-aneh, hanya orang-orang Cina yang cocok bekerja di sana. Oleh karena itu, studi sejarah lebih diarahkan kepada Malaysia. Sir Richard Winstedt berperan penting dalam sejarah kolonial Inggris di Malaysia, dia mengabaikan Singapura sebelum tahun 1941, dan disinggung sangat singkat yaitu suatu tempat perdagangan yang maju dan aman, kecuali beberapa tahun terdapat gangguan dari bajak laut dan peperangan terhadap masyarakat Cina. Usaha untuk menulis sejarah Singapura mendapat perhatian pada tahun 1965 yang terfokus pada pembentukan kesadaran nasional dan kesejahteraan masa depan dengan membangun loyalitas terhadap negara baru. Keunikan inilah membuat para sejarawan merasa kesulitan untuk menulis sejarah Singapura secara standar. Lihat C. Mary Turnbull, 1980, A History of Singapore 1819-1975, Malaysia: Oxford University Press, Cet. III, hal. xiii-xv.

${ }^{2}$ Agama dan kultur mayoritas di atas minoritas akan melahirkan gerakan sparatisme sebagai kristalisasi usaha minoritas untuk mendapat otonomi. Lihat Donald Eugene Smith, 1974, Religion, Politics, and Social Change in the Third World, USA: A Free Press Paperback, Cet. III, hal. 170171.

${ }^{3}$ Lihat G. Means, 1982, "Malaysia: Islam in a Plural Society" dalam C. Caldarela (ed.) Religion and Societies: Asia and Middle East, Boston: Mouton Press, hal. 482. 
sehingga tampak membingungkan dan menyulitkan untuk dilakukan penulisan secara obyektifdalam kerangka ilmiah, termasuk sejarah Singapura yang unik. ${ }^{4}$ Keunikan sejarah Singapura yang rumit merupakan kesulitan tersendiri dalam melacak akar budaya asli Singapura, karena hampir keseluruhan penduduknya adalah imigran sampai proses terjadinya masyarakat seperti yang ada sekarang. ${ }^{5}$ Nama Singapura sendiri adalah sangat paradoks, tidak ada jejak singa yang pernah menginjakkan kaki di Lion City ini. ${ }^{6}$ Tulisan yang berkaitan dengan Singapura awal terkesan melompat-lompat dan terputus-putus. Sesuai dengan laporan singkat P'u Luo Chung utusan Cina sekitar abad 2-3, Singapura telah dihuni oleh penduduk primitif canibalisme dengan ukuran panjang 50-60 inci. Menurut laporan pelayar Arab abad 9 menyebutkan pulau tersebut dengan nama pulau Ma'it. ${ }^{7}$ Abad ke-13 sesuai dengan pelayaran Marco Polo melalui tangan kedua menyebutkan bahwa pulau tersebut dinamakan dengan Tamasek merupakan bagian dari pulau Malayur dengan raja dan bahasa setempat.

${ }^{4}$ Lihat Muhammad Yusuf Hashim, 1990, Kesultanan Melayu Melaka, Kuala Lumpur: Dewan Bahasa dan Pustaka, Cet. II, hal. 5.

${ }^{5}$ Di samping kelangkaan referensi yang standar tentang sejarah awal Singapura, secara komunal sejarah awal Asia Tenggara sangat rumit untuk dibahas terutama yang menyangkut sejarah Islamnya, karena data yang tersedia banyak terjadi kesimpang-siuran informasi. Lihat Azyumardi Azra, "Pendahuluan: Islam di Asia Tenggara" dalam Azyumardi Azra (ed), 1989, Perspektif Islam di Asia Tenggara, Jakarta: Yayasan Obor Indonesia, hal. vi.

${ }^{6}$ Sesuai dengan legenda yang berkembang dan tertuang dalam Malay Annals, nama Singapura berawal dari seorang raja Sriwijaya bernama Sri Tri Buana anak dari raja Chulan merupakan raja India keturunan Alexander Agung. Sri Tri Buana ketika mengadakan perjalanan di sekitar kepulauan, dia melihat cahaya putih di sekitar pulau Tamasek kemudian datang badai yang ingin menghancurkan kapalnya, dan memaksa dia untuk membuang seluruh isi kapal termasuk mahkotanya. Setelah mendarat di Kuala Tamasek, Sri Tri Buana bertemu dengan seekor hewan buas dengan tubuh warna merah, kepala hitam, dan dada wama putih yang kemudian dinamakan Singa. Pertanda inilah raja menamakan perkampungan Tamasek dengan nama Singapura atau Lion City. Lihat C.M. Turnbull, Singapore, hal. 2-3. Kepergian Sri Tri Buana atau dikenal dengan Parameswara akibat serangan dari Kerajaan Majapahit atas Kerjaan Sriwijaya di Palembang. Lihat John F. Cady, 1976, Southeast Asia Historical Development, New Delhi: Mcgraw-Hill, Inc, hal. 154. Hal ini akan berbeda dengan apa yang ditulis Raja Ali Haji bahwa Sri Tri Buana berasal dari Raja Pelembang yang turun dari dari Bukit Siguntang, dia telah berkuasa di Singapura selama lima keturunan sampai raja terakhir di Singapura Iskandar Syah yang memimpin selama 30 tahun di Singapura kemudian pindah ke Melayu. Lihat Virgina Matheson Hooker, 1991, Tuhfat al-Nafis: Sejarah Melayu Islam, terj. Ahmad Fauzi Basri, Kuala Lumpur: Dewan Bahasa dan Pustaka, hal. 129-131. Cerita ini hampir mirip dengan apa yang terekam dalam cerita Hang Tuah bahwa penguasa Singapura berasal dari Sang Petala Dewa yang menurunkan raja-raja Bukit Siguntang dan dari sini menurunkan raja-raja Malaka, Singapura, dan Keling. Lihat Sulastin Sutrisno, 1983, Hikayat Hang Tuah: Analisa Struktur dan Fungsi, Yogyakarta: Gajah Mada University Press, hal. 92-94 dan 172.

${ }^{7} \mathrm{Jika}$ laporan ini benar, maka pada saat itu Singapura masih belum berpenghuni, sesuai dengan arti kata tersebut. 
Referensi paling awal tentang penduduk pribumi Asia Tenggara ada dalam Negarakartagama $1365 . .^{8}$ Menurut informasi yang ada sudah dikenal perkampungan yang disebut dengan Tamasek di kepulauan Singapura. ${ }^{9}$ Menurut keterangan Wang Tayuan pedagang Cina yang menetap selama dua puluh tahun pada pertengahan abad 14 menyebutkan bahwa Tamasek telah dihuni oleh penduduk asli Cina dengan pakaian dan hidup sesuai dengan penduduk pribumi. ${ }^{10} \mathrm{Keberadaan}$ penduduk Cina di Singapura ini diperkirakan karena adanya hubungan Cina dengan kawasan Nusantara sudah terjalin lama. Kekuasaan kerajaan Mongol sudah mencapai kawasan Asia Tenggara yaitu Siam dan Birma Utara, ditolaknya utusan Kubilai Khan oleh Kertanegara raja terakhir Singasari (1268-192) adalah salah satu bukti adanya hubungan ini. Kertanegara sendiri kawin dengan putri raja dari Campa yang masih termasuk kekuasaan Imperium Cina. " Pada tahun 1292 Mongol pernah mengirim pasukan dengan 100 buah kapal dan 20.000 pasukan untuk menguasai Singasari, karena Singasari sudah bubar, maka pasukan Mongol tersebut akhirnya menyebar ke seluruh kawasan termasuk Malaka, ${ }^{12}$ bahkan pasukan Mongol terus ikut berperan dalam berdirinya kerajaan Majapahit. ${ }^{13}$

Pada tahun 1365 Singapura telah diklaim oleh kekuasaan Majapahit, terdapat peninggalan batu besar yang berukuran tinggi 10 kaki panjang 9-10 kaki yang memiliki karekteristik Majapahit. Di samping itu, terdapat sekte keagamaan yang sama dengan periode Singasari. ${ }^{14}$ Setelah menjadi kekusaan Majapahit, Singapura kemudian menjadi kekuasaan Palembang Sriwijaya pada tahun 1390 Iskandar Syah, atau dikenal dengan Parameswara yang mendirikan kerajaan di Singapura selama 5 tahun kemudian mendirikan kerajaan Malaka yang akhirnya menjadi kesultanan setelah rajanya masuk Islam. ${ }^{15}$ Pada awal abad 15, Johor lama dijadikan sebagai ibukota kesultanan dan menjaga Singapura

${ }^{8}$ Negarakartagama dikarang oleh Empu Prapanca pada masa Rajasanegara raja Majapahit yang dikenal dengan Hayam Wuruk. Lihat Bernard H.M. Vlekke, 1965, Nusantara, A History of Indonesia, Nederland: W. Van Hoeve Ltd-The Hague, Cet. VI, hal. 59-61.

Nama Tamasek sendiri berasal dari bahasa Jawa, dalam Negarakertagama disebutkan bahwa nama Tamasek disebabkan oleh kondisi Singapura yang berada di lautan, maka nama tersebut disesuaikan dengan istilah jawa tasek yang berarti laut. Lihat Cril Nortcote Pelinson, 1976, "Singapura" dalam Encyclopaedia Britannica, vol. 20, USA: Encyclopaedia Britannica. Inc., hal. 1709.

${ }^{10}$ Bagi Tumbull sejarah Tamasek abad 14 ini sangat membingungkan karena pada masa itu adalah awal dari Imperium Ming yang melarang perdagangan pribadi, sehingga tidak ada pengembaraan pedagang Cina termasuk Asia Tenggara. Lihat C.M. Turnbull, Singapore, hal. 2.

"Lihat B.H.M. Vlekke, Nusantara, hal. 61-65.

${ }^{12}$ Lihat ibid, hal. 67-68.

${ }^{13}$ Lihat ibid, hal. 66.

${ }^{14}$ Lihat C.M. Tumbull, hal. 3.

${ }^{15}$ Parameswara tidak disebut-sebut dalam sejarah Melayu dimaksudkan untuk menghilangkan kesan tradisi Hindu-Buda pada awal kerajaan Melayu yang berubah menjadi kesultanan setelah rajanya masuk Islam. Lihat M. Yusuf Hashim, Kesultanan, hal. 108-112. 
sebagai pusat pelabuhan (shahbandar). Setelah Portugis menguasai Malaka dan menghancurkan Johor lama tahun 1587 sekaligus menguasai Singapura. Imperium Johor didirikan kembali di Riau-Lingga, Johor, Singapura, dan kawasan timur Sumatera sebagai kepulauan tetangga, kesemuanya berada di bawah kekuasaan satu Sultan, lima Tumenggung dan dua menteri. ${ }^{16}$ Praktis, pada periode kesultanan Johor interaksi Agama dan politik identik, sehingga sangat efektif dalam menciptakan tatanan sosial atas dasar nilai-nilai Islam lokal.

Terdapat perkampungan Bugis di Singapura, di samping sebagai pelaut ulung orang Bugis telah banyak menguasai perdagangan di kawasan selat Malaka, mereka telah membantu Kesultanan Malaka dan mampu mengusir penguasa Minangkabau dari kerajaan Melayu. Dari keberhasilannya ini, Sultan memberi gelar bagi pemimpinnya dengan Yang Dipertuan Muda atau sebagai wakil Sultan untuk diemban secara turun temurun. Bangsa Bugis dan Melayu telah mengadakan power sharing dalam menjalankan pemerintahan Johor yang berpusat di Riau-Lingga, meskipun sering terjadi konflik dalam pembagian tugas, akhirnya kekuasaan bangsa Bugis berpusat di Penyengat. ${ }^{17}$ Pembagian kekuasaan antara bangsa Melayu dan Bugis terjadi pada abad 18, sehingga pada pertengahan akhir abad 18 merupakan periode peralihan yang memusingkan. Terkadang abad ke-18 ini disebut abad Bugis yang menguasai percaturan politik dan perdagangan. Di Singapura sendiri terdapat beberapa ratus orang Bugis, di samping orang Jawa, Arab, Cina, dan India. ${ }^{18}$ Akulturasi Islam dan politik lebih disebabkan oleh pertentangan kepentingan etnis.

Sementara para imigran Arab pada abad 13 telah menguasai jalur perdagangan di kawasan Asia Tenggara dan banyak mendirikan koloni-koloni serta menetap dengan membentuk kelas masyarakat yang agak eksklusif, Singapura menjadi jalur keluar Nusantara oleh para pedagang Arab yang berlayar sampai ke Cina dan Jeddah. ${ }^{19}$ Tidak heran kalau sebagian besar orang Arab yang menyebar ke kawasan Nusantara berasal dari Singapura setelah terlebih dahulu tinggal di Batavia. ${ }^{20}$ Pada awal kedatangan Reffles ${ }^{21}$

${ }^{16}$ Lihat C.M. Turnbull, Singapore, hal. 3-5.

${ }^{17}$ Lihat Barbara Waston Andaya dan Virginia Matheson," Raja Ali Haji: Antara Pemikiran Islam dan Tradisi Melayu" dalam Alhikmah no, 4. Vol. vi, 1995, Bandung: Yayasan Muthahhari, hal. 107.

${ }^{18}$ Lihat David Joel Steinberg, 1971, In Search of Southeast Asia, Singapura: Oxford University Press, hal. 134.

${ }^{19}$ Lihat L.W.C. Van den Berg, 1996, Hadratulmaut dan Koloni Arab di Nusantara, terj. Rahayu Hidayat, Jakarta: INIS, hal. 119. Komunitas Arab di Singapura biasanya membuat kolonikoloni dengan membangun masjid sebagai ciri khas mereka dan menempati kelas sosial tersendiri. Lihat D. Van Der Meulen \& H. Von Wissmann, 1969, Hadratmaut Some of Its Mysteries Unveited, Leyden: E.J. Brill. Ltd. hal. 33.

${ }^{20}$ Lihat L.W.C. Van den Berg, Hadratulmaut, hal. 73.

${ }^{21}$ Reffles lahir tahun 1781, dia bergabung dengan EIC di London pada tahun 1805 sebagai jurutulis, dan dipromosikan sebagai asisten sekretaris pada Kepresidenan Penang, selanjutnya 
di Singapura, komposisi penduduknya adalah sekitar 1000 orang terdiri dari 500 orang Kalang, ${ }^{22} 200$ orang Selat, 150 orang Gelam dan sisanya adalah orang laut. ${ }^{23}$

Setelah kedatangan Reffles, merupakan titik balik bagi Singapura menuju kota modern. Dua tahun kemudian Singapura telah menjadi kota kosmopolitan baru dengan penduduk sekitar 5000 orang, 3000 orang Melayu, 1000 orang Cina, 5-6 ratus orang Bugis, sisanya adalah orang Arab, India, Eropa, Armenia sebagai kelompok minoritas. ${ }^{24}$ Atas dasar ide Reffles inilah Inggris secara cepat telah menguasai Jawa, Timor, Makassar, dan Palembang sebagai daerah jajahan. ${ }^{25}$ Kedatangan Reffles di Singapura di samping telah membawa kemajuan besar, tetapi telah memecah bangsa Melayu dan mengantarkan pada degradasi tradisi Melayu yang identik dengan Islam. Reffles juga telah memperuncing konflik intern Kesultanan Melayu dengan mengangkat seorang Sultan di Singapura, sementara Belanda mengangkat seorang Sultan lain di Riau-Lingga. ${ }^{26}$ Kondisi ini diperparah dengan adanya perjanjian antara Inggris dan Belanda pada tahun 1824 untuk membagi dua dunia Melayu. Kerajaan Johorpun terpecah menjadi dua dengan pekembangan yangjauh berbeda. Para elit penguasa Singapura semakin tenggelam dalam gaya hidup yang diperkenalkan oleh Inggris, sementara Riau tetap mempertahankan identitasnya sebagai pengawal tradisi dan cara hidup warisan Melayu. ${ }^{27}$ Singapura mulai mengalami pergeseran secara drastis meninggalkan tradisi induknya Malayu yang dibentengi oleh nilai-nilai Islam yang sudah mentradisi. Eksistensi Sultan di Singapura hanya dijadikan simbol bagi alat legitimasi kekuasaan Inggris dalam menggelar usahanya. Sultan telah kehilangan fungsi utama sebagai pengawal dan pelestari tradisi Melayu.

Dengan dijadikannya kota Singapura sebagai kota industri dan pusat perdagangan, Singapura menjadi pusat tujuan imigran terutama dari Cina. Akhimya

menjadi Letnan Gubernur Jawa 1811-1816, terakhir sebelum ke Singapura dia menjadi Letnan Gubernur di Jambi tahun 1818. Lihat C.M. Tumbull, Singapore, hal. 6.

${ }^{22} \mathrm{Asal}$-usul orang Kalang diasumsikan sebagai orang Jawa yang tersubordinasikan, karena secara ras berbeda dan dianggap sebagai orang asing di negerinya sendiri. Informasi lebih lanjut, lihat Claude Guilhot, "Orang Kalang di Pulau Jawa: Juru-juru Angkut dan Pegadaian" dalam Henri Chamber Loin dan Hasan Ma'arif Ambari, 1999, Panggung Sejarah: Persembahan kepada Prof. Dr. Denys Lombard (Jakarta: Yayasan Obor Indonesia, hal. 323-324.

${ }^{23}$ Orang laut atau orang Selat adalah komunitas yang hidupnya di laut serta memiliki perkampungan di pantai-pantai. Mereka memiliki peran yang sangat penting dalam mengawal tegaknya kerajaan Sriwijaya, karena menjaga keamanan laut dari ancaman luar. Mereka taat kepada raja yang berkuasa, oleh karena itu mereka diberi gelar oleh raja Sriwijaya sebagai raja lautan (King of the ocean lands) Orang-orang laut inilah yang mengawal Parameswara ke Singapura dan menidirikan kerajaan di sana. Lihat M. Yusuff Hashim, Kesultanan, hal. 144-145, dan 237.

${ }^{24}$ Lihat C.M. Turnbull, Singapore, hal. 14.

${ }^{25}$ Lihat, B.H.M. Vlekke, Nusantara, hal. 295.

${ }^{26}$ Lihat Barbara W Andaya dan V. Matheson, "Raja Ali Haji", hal. 107. Untuk campur tangan Eropa dalam memecah belah bangsa Melayu, lihat C.M. Turnbull, Singapore, hal. 9-10.

${ }^{27}$ Lihat B.W.Andayana dan V. Matheson, "Raja Ali Haji", hal. 108. 
penduduk Melayu semakin terdesak dan menjadi penduduk minoritas di negeri sendiri. Adapun faktor yang menyebabkan imigran Cina menjadi penduduk mayoritas adalah:a) Adanya promotor Cina Tan Che Sang saudagar kaya Riau yang pindah ke Singapura dan bekerjasama dengan W. Farqohar seorang Residen Singapura untuk memasukkan imigran Cina secara besar-besaran. b) Sementara imigran Bugis diekstradisi oleh Farqohar ke Riau yang dipimpin oleh Arong Bilawa. c) Reffles sendiri ingin melawan komunitas Arab yang telah menguasai rute perdagangan Asia Tenggara selama seabad ${ }^{28}$ d) Pada tahun 1870-an Singapura dibanjiri imigran Cina rata-rata 25-30 ribu setiap tahunnya. ${ }^{29} \mathrm{e}$ ) Di samping itu terjadinya perkawinan antara pembesar kerajaan dengan para etnis Cina. Demikian halnya terhadap etnis-etnis lain, Persia, Arab, Jawa dan India. Dari hasil perkawinan ini, para keturunannya menempati kelas elit masyarakat dan berpengaruh besar terhadap kelompok etnisnya $0^{30} \mathrm{Populasi}$ sosial Singapura pada tahun 1961 adalah 1.712 .600 terdiri dari 1.287 .700 orang Cina, 240.200 orang Melayu, 19.916 orang Eropa yang lainnya campuran ${ }^{31}$ Dengan demikian pada tahun tersebut komunitas Cina sudah mencapai sekitar 70 persen lebih. Tidaklah mengherankan sebagai mayoritas penduduk akan menumbuhkan perasaan nasionalisme baru di Singapura yang didasarkan pada persamaan ras dan etnis. Komposisi komunitas di Singapura telah menggeser dan mengambil peran politik dari etnis Melayu ke tangan etnis Cina. Pergeseran ini telah mengarah pada gerakan separatisme yang dilandasi pada perbedaan mendasar antara tradisi dan budaya Melayu Islam dengan Cina yang non-muslim.

\section{Proses menuju Singapura merdeka}

Pendudukan Inggris atas bangsa Melayu menumbuhkan kesadaran politiksebagai artikulasi anti Cina yang telah menguasai sektor ekonomi Melayu, tetapi mereka lemah dalam bidang politik. ${ }^{32}$ Inggris yang telah menjadikan Melayu sebagai negara federal, meskipun memberi keleluasaan dalam bidang politik, tetapi Singapura yang mayoritas penduduknya adalah Cina, sangat sulit untuk bergabung dengan Melayu. Menyadari hal itu, pemerintah memberi prioritas bagi masalah-masalah budaya, keamanan, dan agama dengan mengontrol masalah-masalah tersebut. ${ }^{33}$ Secara budaya kata Melayu yang identik

${ }^{28}$ Lihat C.M. Turnbull, hal. 14-15. Perlakuan tidak adil Reffles terhadap penduduk Arab ditunjukkan ketika menghukum seorang Arab Sayyid Yasin dengan diarak dan digantung selama empat hari sebagai pelajaran bagi orang muslim Melayu dan Arab lainnya. Lihat ibid, hal. 25.

${ }^{29}$ Lihat ibid., hal. 82.

${ }^{30}$ Lihat M. Yusuf Hashim, Kesultanan, hal. 313-315.

${ }^{31}$ Lihat Melville W. Keldman dan Rudolph T Yeatman Jr, 1965, The Word university, Encyclopedia, vol. 10, USA: Wasington DC Pablishings, hal. 4631.

${ }^{32}$ Lihat John F. Cady, Southeast Asia, hal. 452,

${ }^{33}$ Lihat Ervin I.J. Rosenthal, 1965, Islam in the Modern Nation State (Cambridge: Cambridge University Press, hal. 287. 
dengan Islam sebenamya bukanlah hasil akhir dari analisa rasional, tetapi sebagai simbol dari Melayu. Dari segi kultur ini, masyarakat Cina lebih sulit untukmasuk dalam komunits Melayu. ${ }^{34}$ Simbol Islam yang dijadikan komoditas politik oleh etnis Melayu ternyata justru telah mereduksi nilai universalitas Islam yang melahirkan pertentang etnis yang semakin tajam di tengah pluralitas etnis Singapura.

Perbedaan antara suku Cina yang menguasai perekonomian dan aktivitas profesional, sementara orang-orang Melayu di bidang pertanian dan pos-pos administrasi, ${ }^{35}$ bukan tidak membawa masalah. Munculnya partai UMNO (United Malay's Nation Organisation) sebagai wadah aspirasi politik bangsa Melayu, dan MCA (Malayan Chinese Assosition) merupakan wadah aspirasi politik orang-orang Cina. Perbedaan ini akhirnya mengkristal dan terakumulasi dengan berdirinya negara Malaysia yang identik dengan negara Melayu. ${ }^{36}$ Meskipun terdapat orientasi baru dalam apresiasi politik Cina-Melayu dari orang-orang didikan Barat, tetapi ketegangan-ketegangan tetap terus berlanjut. Usaha reunifikasi banyak mengalami kendala, terutama dengan munculnya gerakan sayap kiri multi rasial merupakan gabungan gerakan komunis Cina dan PanIndonesia. Tanggal 1 Februari 1948 didirikan negara federasi baru, tetapi Singapura tetap menjadi negara sempalan sebagai basis utama Partai Komunis Cina MCA (Malayan Communist Party) yang menjadi identifikasi utama bagi warga Cina. ${ }^{37}$

Sementara Malaysia menjadi negara merdeka dengan bentuk federasi 31 Agustus 1957, Singapura berlahan bergerak menuju kemerdekaan. Seorang intelektual brilian berpendidikan hukum dari Universitas Cambridge, Lee Kuan Yew dengan PAP(People's Action Party) yang secara esensi adalah partai sosialis pragmatis, telah mendapatkan simpati sangat besar dari sayap kiri Cina dan kelompok komunis. Dengan slogan Malaysia untuk bangsa Malaysia “A Malaysian Malaysia”. Gerakan ini membuat Kuala Lumpur kebingungan, ditambah lagi dengan adanya konfrontasi dengan Jakarta. Gerakan tersebut tampaknya tidak dapat terbendung, akhirnya, Kuala Lumpur mempersilahkan Singapura untuk meninggalkan negara federasi Malaysia dan menjadi negara kota (city state). PAP melanjutkan pemerintahan dengan tiada tantangan yang berarti untuk membangun Singapura seperti sekarang ini. ${ }^{38}$ Etnis Cina telah berkuasa penuh atas Singapura dan menjadi tuan rumah dalam percaturan politik di tanah perantauan. Kekuatan Islam hanya

${ }^{34}$ Lihat R. Von Denveden, 1987, “Melayu: Islam and Muliethnics Politics" dalam John L Esposito (ed.) Islam in Asia: Religion, Politics and Society, Oxford: Oxford University Press, hal. 179-180.

${ }^{35}$ Lihat ibid., hal. 178.

${ }^{36}$ Lihat John Obert Voll, 1997, Poltik Islam, Kelangsungan dan Perubahan di Dunia Modern, terj. Ajat Sudrajat, Yogyakarta: Titian Ilahi Press, hal. 191-193.

${ }^{37}$ Lihat David I. Stenberg, In Search, hal. 365-367.

${ }^{38}$ Lihat ibid, hal. 370-372 
menjadi letupan isu politik guna memperoleh legalitas politik dari penguasa bagi terjaminnya eksistensi dan terlaksananya hukum Islam bagi para pemeluknya.

Di bawah kekuasaan Gok Chok Tong, Singapura dengan luas $612,4 \mathrm{~km}$ persegi atau sebesar Jakarta dengan populasi sekitar $80 \%$ adalah orang Cina, selebihnya campuran Melayu, Asia dan Eropa. Kini masyarakat Cina perantauan seolah tinggal di tanah leluhurnya di Singapura yang menguasai bidang politik dan ekonomi. Dari sisi politik, Singapura merupakan negara yang relatif paling aman di Asia Tenggara, bahkan di kawasan Asia dan paling stabil dalam bidang ekonomi. Posisi Singapura sebagai pusat menjadi standar bagi pusat informasi bisnis bursa internasional di kawasan ASEAN.

\section{Hubungan Agama dan Politik}

Dalam kaitannya hubungan agama dengan politik J.M. Yinger memberikan tiga tipologi: ${ }^{39}$ a) Komunitas agama dan politik identik, fungsi agama terintegrasi dalam sistem politik. Lebih jauh fungsi agama juga sangat membantu dalam menciptakan individuindividu sosial yang secara substansial terbentuk dalam norma-norma sosial. ${ }^{40} \mathrm{~b}$ )Agama sebagai tambahan dalam kebijakan politik, seringkali terjadi kontradiksi dalam pengintegrasian keduanya. Di sini praktek-praktek dan kepercayaan agama menjadi salah satu manifestasi situasi politik. ${ }^{41} \mathrm{c}$ ) Kepentingan-kepentingan agama dan politik selalu kontradiksi, terjadi tekanan yang terus menerus antara agama dan politik. Implikasi dari hubungan di atas adalah: Pertama, identitas kelompok agama menjadi satu bagian yang integral dalam sosial. Kedua, agama digunakan sebagai kekuatan politik, hubungan agama dengan politik menjadi lebih komplikatif dalam masyarakat. Ketiga, tantangantantangan agama terhadap otoritas politik begitu kuat, sehingga penjabaran agama berada di tangan penguasa. Dalam kondisi semacam ini, universalitas agama masih dirasa tidak mungkin. ${ }^{42}$

Adapun segmentasi agama dan pluralitas dalam kaitannya dengan politik dapat dijelaskan dengan beberapa model. a) Perbedaan agama mungkin agak berimbang yang didasarkan pada kelas sosial, etnik, kelompok bahasa, dan daerah. Hal yang demikian, agama akan memberikan kekuatan pada stratifikasi sosial. b) Perbedaan agama mungkin akan melampaui garis-garis kelas, akan tetapi keseimbangan etnik, bahasa, dan kawasan akan menempati kelompok-kelompok yang paralel dalam struktur sosial.

${ }^{39}$ Lihat J. Milton Yinger, 1970, Scientific Study of Religion, New York: Macmillan Publishing. Inc, hal. 409.

${ }^{40} \mathrm{Kasus}$ paling mudah dideteksi adalah di negara-negara Islam seperti di Republik Islam Iran, Pakistan, Arab Saudi dan negara Islam lainnya.

${ }^{41}$ Kasus yang paling mudah adalah di Indonesia, fungsi agama sebagai suplemen dalam perpolitikan, bahkan terkadang didajikan sebagai komudite politik. Fenomena semacam ini terjadi di banyak negara yang mayoritas penduduknya beragama Islam.

${ }^{42}$ Lihat J.M. Yinger, Scientific, hal, 410-413. 
c) Perbedaan agama bersifat sangat independen. Masing-masing agama dapat ditentukan dalam setiap kelas dan di antara kelompok etnik. ${ }^{43}$ Sementara itu, aktor politik dapat dikategorikan sebagai berikut: Kepemimpinan dan fungsionaris agama secara individual berpengaruh besar dalam kesetiaan politik masyarakat. Interes kelompok dan asosiasi lebih aktif dalam mempertahankan hukum Islam dan memperjuangkan terbentuknya negara Islam. Munculnya partai-partai politik agama dengan beberapa kategari, komunal, sektarian, tradisional, dan modern..$^{44}$ Manifestasi politik agama di Singapura diekspresikan dalam bentuk partisipasi aktif atas nama etnis.

Partai komunal, timbul sebagai respon terhadap aktualitas atau konflik yang laten terhadap militan agama dam pluralitas sosial. E. Smith mengindikasikan bahwa dalam kasus Asia secara umum, Islam bertendensi intoleran terhadap agama lain, karena hukum Islam sudah dianggap final dan lengkap oleh para penganutnya. ${ }^{45}$ Obert Voll menyebutkan bahwa selama Islam di Malaysia bersifat komunal, maka Islam memiliki potensi sebagai pemecah. ${ }^{46}$ Kerusuhan komunal Cina-Melayu di Kuala Lumpur menjelaskan ketidakpuasan dan permusuhan yang ditimbulkan di kalangan muslim Melayu. Cina dianggap sebagai suatu ancaman terhadap status dan identitas Melayu yang diidentikkan dengan Islam. ${ }^{47}$ Sebagaimana ditunjukkan oleh sikap para fungsionaris Pan Malaysian Islamic Party (PIM atau PAS), jika partainya menang, maka bagi golongan non-muslim dan non-Melayu akan dipulangkan ke negeri asalnya atau dilempar ke laut Cina selatan. Pernyataan semacam ini jelas mencemaskan golongan Cina dan golongan-golongan nonMelayu lainnya. ${ }^{48} \mathrm{Kondisi} \mathrm{semacam} \mathrm{ini} \mathrm{akan} \mathrm{meningkatkan} \mathrm{rasa} \mathrm{solidaritas} \mathrm{etnis} \mathrm{non-}$ Melayu terutama Cina dan akan meningkatkan rasa nasionalisme baru untuk memisahkan diri dari komunitas Melayu di Singapura.

Dalam konteks Singapura dengan kerumitan etnis komunitas muslim Singapura yang digabung dengan status Singapura yang unik sebagai sebuah negara ciptaan kolonial. Dengan kurangnya elit politik pribumi, memungkinkan kekuatan asing dapat membangun suatu sistem pengaturan tak langsung, secara fundamental berbeda dengan daerah Melayu secara umum. Pada masa kèrajaan awal di Sịgapura, terdapat indikasi hukum telah diterapkan oleh Iskandar Syah yaitu dengan menggunakan sistem kerajaan Hindu. Dia

${ }^{43}$ Lihat ibid., hal. 425-426.

${ }^{44}$ Lihat Donald Eugene Smith, 1970, Religion and Political Development, Boston: Little Brown \& Company, hal. 127.

${ }^{45}$ Kasus India dijadikan contoh yang faktual oleh Smith. Lihat Donald Eugene Smith, 1966, South Asia, Politics and Religion, New York: Pricenton university Press, hal. 19.

${ }^{46}$ Lihat J. Obert Voll, Politik Islam, hal. 415.

${ }^{47}$ Lihat John L Esposito, 1995, Ancaman Islam, Mitos atau Realitas? Terj. Abd Rahman dan Muis (Cet. II; Bandung: Mizan, hal. 23-24.

${ }^{48}$ Lihat Mohammad Abu Bakar, "Islam dan Nasionalisme pada Masyarakat Melayu Dewasa ini" dalam Taufik Abdullah dan Sharon Siddique, Tradisi, hal. 172. 
memerintah dengan adil dan bersikap moderat yang telah banyak mendatangkan dukungan untuk mempertahankan Malaka. Pada masa Kesultanan Malaka hukum Islam telah diterapkan, meskipun masih terlihat keterpengaruhan budaya Hindu yang ditinggalkan oleh tradisi sebelumnya. UU khusus untuk Singapura biasanya disebut dengan UU laut, sementara untuk Melayu secara umum disebut dengan UU darat. Terdapat 24 pasal dari 25 pasal UU laut yang menyangkut peraturan laut di Singapura, sementara dalam UU darat terdapat 5 pasal dari 44 pasal yang memuat peraturan laut. Dari UU laut tersebut menyangkut pengaturan tentang tata cara pelabuhan, larangan-larangan dan tanggungjawab nahkoda, peraturan Syahbandar. ${ }^{49}$ Dengan demikian, meskipun manifestasi politik diwujudkan dalam bentuk pemberlakuan hukum Islam, namun khusus Singapura UU yang diterapkan memiliki spesifikasi yang berkaitan dengan fungsi dan status Singapura.

Setelah kedatangan Reffles di Singapura, dia menerapkan semua administrasi yang pernah dirintisnya di Jawa. ${ }^{50}$ Untuk mengakomodasi kepentingan pemerintah Inggris dan penguasa setempat Reffles menempatkan seorang penguasa setempat, yaitu Sultan Husain dengan tujuan untuk mendapatkan legitimasi dalam mengembangkan perdagangan dan perindustrian di kawasan Singapura yang strategis. ${ }^{51}$ Sementara itu, untuk memenuhi aspirasi tuntutan pribumi dalam menjamin terlaksananya hukum Islam, dia mengeluarkan kebijakan hukum yang berisi tentang penghormatan hukum agama untuk diberlakukan, khususnya hukum keluarga yaitu tentang perkawinan dan pewarisan, serta menghormati hukum adat Melayu. ${ }^{52}$ Sementara hukum Inggris diberlakukan sesuai dengan kepentingan yang bermanfaat dengan mempertimbangkan kebiasaan penduduk. ${ }^{53}$

Setelah ditinggalkan Reffles, Singapura telah mengalami perkembangan yang pesat dengan jumlah sekte-sekte dari berbagai bangsa, tetapi kebijakan politik hukum yang diberlakukan tetap berlandaskan penghormatan terhadap agama dan adat istiadat dari berbagai sekte, termasuk pengakuan terhadap keabsahan hukum keluarga bagi umat Islam. ${ }^{54}$ Namun demikian, kebijakan politik Inggris terhadap kepentingan umat Islam dalam menjalankan hukum Islam masih sebatas pengakuan, dan belum memberikan aturan pelaksanaannya dalam bentuk hukum positif. Dengan demikian, pelaksanaan hukum Islam

${ }^{49}$ Lihat M. Yusuf Hashim, Kesultanan, hal. 253-255.

${ }^{50}$ Selama keberadaannya di Jawa Reffles telah melakukan reformasi hukum dan administrasi yang cukup berarti bagi perubahan admistrasi-administrasi di Jawa di antaranya: merevisi tentang aturan-aturan hubungan Gubenur Batavia dengan raja-raja Jawa. Reorganisasi administrasi intitusiinstitusi dan hukum. Sistem perpajakan dan administrasi-administrasi modern ini ditujukan untuk menggantikan sistem feodalisme. Lihat B.H.M. Vlekke, Nusantara, hal. 262-269.

${ }^{51}$ Lihat C.M. Turnbull, Singapore, hal. 35 .

${ }^{52}$ Lihat ibid., hal. 36-37.

${ }^{53}$ Lihat ibid.

${ }^{54}$ Lihat ibid., hal. 39 . 
di luar campur tangan pemerintah. Dalam mengantisipasi hal tersebut masyarakat secara mandiri mengangkat seorang kadhi dari masing-masing kelompok etnis yang bertindak sebagai pelaksana hukum Islam, khususnya tentang perkawinan, meskipun keberadaan $k a d h i$ ini secara formal tidak diakui, tetapi segala yang ditetapkan dianggap absah..$^{55}$ Upaya untuk mempertahankan eksistensi hukum Islam ini dilandasi oleh adanya keyakinan bahwa konsepsi hukum Islam memiliki nilai yang pasti, karena bersumber dari Yang Mutlak. ${ }^{56}$

Kepala kampung memegang peran penting dalam pengaturan dan pengawasan yang berkaitan langsung dengan urusan penduduk. Dalam kaitannya dengan pelaksanaan agama secara praktis, penduduk mengurus sendiri, keberadaan masjid-masjid yang berorientasi pada komunitasnya dengan mengangkat imam masjid dari kampung yang sama. Dengan demikian, interaksi antara penduduk pribumi dengan penguasa Inggris sangat kecil. Inggris lebih mengutamakan penguasaan pelabuhan dan perdagangan, kebijakan politik yang menyangkut penduduk masih lemah, hanya sebatas pengakuan terhadap eksistensi penduduk beserta adat dan agama yang dianutnya. ${ }^{57}$ Partisipasi aktif komunitas Islam terkesan masih sangat terbatas dan parsial.

Semakin banyaknya jumlah imigran etnis Cina telah membuat mereka merasa sebagai komunitas Singapura. Posisi mereka semakin kuat untuk ikut berperan aktif dalam pengaturan masalah penduduk, terutama yang berkaitan langsung dengan kepentingan komunitasnya sebagai sebuah upaya perlindungan dari segala ancaman. Pemerintah Inggris merespon dengan mengangkat seorang Cina sebagai pelindung komunitasnya. Penduduk muslim yang merasa diri mereka sebagai penduduk pribumi atau anak negeri, melihat perlakuan terhadap penduduk Cina tersebut memberikan reaksinya dengan mengajukan petisi kepada Gubernur untuk mengangkat seorang pejabat yang berfungsi sebagai $k a d h i$ yang mengurusi masalah-masalah perkawinan di kalangan umat Islam. Pemerintah mengakomodir aspirasi tersebut dengan menyerahkan sepenuhnya kepada komunitas-komunitas muslim untuk merekomendasikan orang-orang yang mereka pilih dan diajukan kepada Gubernur untuk diangkat sebagai kadhi ${ }^{58}$ Meskipun secara konstitusi eksistensi dan status hukum perdata Islam diakui, tetapi hak perlindungan komunitas muslim tidak diberikan secara konstitusional. Perbedaan mendasar adalah disebabkan oleh adanya perbedaan kepentingan antara komunitas Cina dengan komunitas muslim, yaitu antara kepentingan suku dan agama.

${ }^{55}$ Lihat $i$ ibid.

${ }^{56}$ Lihat J.N.D. Anderson, 1994, Islamic Law in The Modern World (New York: New York University Press, hal. 3.

${ }^{57}$ Para penduduk imigran kebanyakan tidak tahu apakah di tempat mereka tinggal yaitu Singapura memiliki pemerintahan atau tidak. Baik imigran atau penduduk setempat mengurus kepentingan kelompok masing-masing atas inisiatif bersama, atas dasar kesamaan kepentingan, etnis, dan agama. Lihat C.M. Turnbull, Singapore, hal. 78.

${ }^{58}$ LihatTaufik Abdullah dan Sharon Siddique, Tradisi, hal. 395 
Tampaknya, seberapa besar terakomodasinya kepentingan kelompok oleh penguasa adalah paralel dengan seberapa besar partisipasi kelompok tersebut dalam ikut berperan memegang kebijakan pemerintah. Masyarakat Cina yang menempati komunitas mayoritas, mereka telah diberi wadah 'Dewan Penasehat Cina" sebagai sarana dialog antara penguasa Inggris dengan komunitas Cina. Dengan terbentuknya wadah tersebut, banyak keturunan Cina tampil sebagai anggota-anggota pegawai pemerintahan, penilik persewaan, dan menjadi hakim setempat. Dalam komunitas muslim, faktor kesukuan memainkan peran penting dalam mengadakan tuntutan-tuntutan untuk partisipasi aktif pemerintahan. Sejak dilibatkannya warga muslim khususnya Arab dan India dalam berbagai dewan pekerja Inggris pada awal abad 20, paling tidak komunitas muslim telah memiliki kepemimpinan yang dapat memprakarsai dialog dan mengadakan pendekatan untuk memperjuangkan kepentingan mereka. Namun demikian, proses panjang sangat mewarnai sampai terbentuknya wadah yang khusus menangani masalah-masalah agama, meskipun masih dicampur dengan agama Hindu. ${ }^{59}$ Pemerintah Inggris tampak kurang akomodatif terhadap kepentingan agama dengan tidak mempertimbangkan perbedaan mendasar antara agama Islam dan Hindu.

Organisasi dan perkumpulan muslim juga memainkan peran yang sangat penting dalam mengadakan penekanan-penekanan terhadap pemerintah kolonial. Sebagaimana pertemuan yang diadakan oleh Institut Muslim telah mengeluarkan resolusi secara bulat yang menyerukan untuk diberikan dua kursi bagi komunitas muslim, satu bagi muslim Melayu yang lainnya untuk non Melayu. Pemerintah mengabulkan permintaan tersebut dengan mengangkat seorang Melayu dan seorang Arab. Secara natural ajaran agama dalam kancah politik merupakan kaunter terhadap proses sekularisasi dalam bidang hukum di dunia Islam. ${ }^{60}$ Pada dasarnya evolusi kesadaran komunitas muslim Singapura untuk mengadakan tekanan-tekanan terhadap pemerintah kolonial lebih dilandasi oleh adanya terjaminnya pelaksannan syari'at Islam, terutama tentang hukum keluarga yang masih dianggap suci dan sakral bagi umat Islam. Sebagaimana yang terjadi di banyak negara yang berpenduduk mayoritas muslim, benturan pertama dengan kekuasaan adalah adanya upaya untuk mempertahankan hukum Islam dari penggantian hukum-hukum Barat modern yang telah mendominasi di seluruh dunia Islam pada masa dan setelah kolonial. ${ }^{61}$ Akumulasi perlawanan politik terhadap proses sekularisasi biasanya diformulasikan dalam bentuk partai-partai poltik sebagai sarana untuk mempertahankan terpeliharanya nilainilai dan hukum Islam. ${ }^{62}$ Dalam kasus Singapura sebagai negara-kota dengan asal suku

\footnotetext{
${ }^{59}$ Proses untuk mendapatkan wadah yang dapat menangani agama secara mendiri sampai hampir setengah abad. Lihat ibid., hal. 396-397.

${ }^{60}$ Lihat D.E. Smith, Religion and Political, hal. 124.

14.

${ }^{61}$ Lihat Abdullahi Ahmed An-Naim, 1994, Dekonstruksi Syariah (Yogyakarta: LPiS, hal.
}

${ }^{62}$ Lihat ibid., hal. 125 
bangsa yang beragam, interaksi agama politik lebih ditunjukkan dengan reaksi sebatas kelompok suku. Para migran muslim secara bertahap mengembangkan elitnya sendiri dan mengindentifikasi diri mereka bersama komunitas muslim yang lebih luas. ${ }^{63}$

Pasca perang dengan Jepang, Inggris mengaktifkan kembali lembaga-lembaga yang menangani masalah-masalah agama. Tuntutan kelompok muslim semakin berkembang, yaitu menuntut untuk diadakannya sebuah Peradilan Syari'ah, akhimya terealisir pada tahun 1958. Peran para kadhi yang sebelumnya bersifat desentralistik, menjadi lebih terkoordinasi dalam Peradilan Syari'ah, kekuasaannya semakin luas, tidak hanya menangani masalah perkawinan, tetapi juga menyangkut masalah warisan. ${ }^{64}$ Puncak dari keberhasilan komunitas muslim Singapura dalam menuntut legalitas penerapan hukum Islam adalah dengan dibentuknya MUIS (Majelis Ugama Islam Singapura) yang dikelola oleh Kementerian Pembangunan masyarakat. Akhirnya eksistensi pelaksanaan hukum bagi pemeluknya diperkuat dengan diundangkannya UU pelaksanaan hukum Islam pada tanggal 25 Agustus 1966 setahun setelah Singapura keluar dari negara federasi Malaysia. ${ }^{65}$ Kodifikasi hukum positif dalam bentuk UU melalui Administration of Muslim Law Act (AMLA) merupakan kulminasi hasil tawar menawar politik umat Islam Singapura. Meskipun Administrasi itu sendiri bukanlah materi hukum Islam, tetapi UU ini memberikan ruang fleksibelitas bagi Dewan Agama Islam, Peradilan Agama, Pencatat perkawinan Islam dalam menerapkan hukum syari'ah. ${ }^{66}$ Perundang-undangan ini tampaknya lebih terpusat pada peran pemerintah dalam mengangkat beberapa anggota dewan yang dikukuhkan dengan undang-undang.

Langkah selanjutnya untuk memperkuat posisi umat Islam dalam partisipasi politik adalah menuntut agar MUIS dijadikan sebagai badan hukum penasehat Presiden Singapura dalam hal-hal yang berkaitan dengan umat Islam. Keanggotaan MUIS diangkat langsung oleh presiden dengan berdasarkan pada rekomendasi dari menteri. Para anggota merupakan orang-orang yang dicalonkan oleh komunitas-komunitas muslim Singapura. Setelah dalam kedudukan politik menjadi kuat, orientasi umat Islam Singapura mengarahkan kelembagaannya kepada kepentingan umat yang lebih luas, yaitu dalam bidang mu'amalah. Pengelolaan zakat harta, zakat fitrah, dan urusan waqaf termasuk urusan haji semuanya ditangani oleh MUIS. Sejumlah harta yang terkumpul dialokasikan untuk pembangunan masjid-masjid, pengembangan lembaga pendidikan, manasik haji, perpustakaan, dan berbagai kegiatan keagamaan lain bagi umat Islam. ${ }^{67}$ Kemauan baik

${ }^{63}$ Lihat Taufik Abdullah, Sharon Siddique, Tradisi, hal. 400-401.

${ }^{64}$ Lihat ibid., hal.402.

${ }^{65}$ Lihat ibid., hal. 403-404.

${ }^{66}$ Lihat Sudirman Tebba (ed.), 1993, Perkembangan Mutakhir Hukum Islam di Asia Tenggara, Bandung: Mizan, hal. 112-113.

${ }^{67}$ Lihat $i b i d$., hal. 406-407. 
politik pemerintah Singapura terhadap komunitas muslim diwujudkan dengan mengangkat seorang mufti yang mengetuai Komite Fatwa. ${ }^{68} \mathrm{Badan}$ ini sangat besar artinya bagi masyarakat untuk mengadakan konsultasi masalah-masalah agama. Jika dianalogkan dengan Indonesia, keberadaan Komite Fatwa sejajar dengan MUI, sementara MUIS sejajar dengan Departemen Agama.

Kondisi politik Singapura yang stabil, sangat mempengaruhi aktivitas umat Islam dalam menata kehidupan sosial yang lebih luas. Fenomena yang berkembang saat ini adalah umat Islam memandang komunitasnya sebagai pendorong mereka untuk dapat mencurahkan segala aspirasi yang berkembang, dan sebagai sarana untuk mengorganisasikan kegiatan-kegiatan mereka bagi masa depan yang lebih baik. Terbentuknya MENDAKI (Mejelis Pendidikan Anak-anak Muslim) merupakan sarana untuk memperbaiki pendidikan bagi generasi muslim Singapura. Dibentuknya DAMAIS (Dana Perwalian Muslim) berfungsi sebagai proyek perjalanan haji dan memperluas fungsinya dengan menggunakan mekanisme pengumpulan sumbangan yang telah ditetapkan. ${ }^{69}$ Dengan demikian, dari lingkup hukum perdata, komunitas muslim Singapura telah mengaktualisasikan dalam bentuk yang lebih luas, tidak hanya menyangkut hukum keluarga, tetapi dalam bidang pendidikan dan sosial ekonomi umat. Kesemuanya itu merupakan proses panjang dari interaksi kepentingan umat Islam dengan realitas politik, yang didasarkan atas jiwa syari'ahnya. Proses tersebut tampaknya tetap akan terus berlangsung seiring dengan perubahan dan perkembangan respon penguasa terhadap kepentingan umat Islam. Dalam komunitas sosial yang bercorak pluralisme, setiap komunitas akan memiliki kesamaan loyalitas politik. Komunitas-komunitas agama akan terpolitisasi oleh situasi-situasi konflik dengan isu-isu riil sosial, politik, dan ekonomi. Di sini agama akan memainkan peran penting yang berfungsi sebagai simbol identitas suatu kelompok. ${ }^{70}$ Kesadaran komunal yang didasarkan pada kepentingan bersama akan diaktualisasikan dalam bentuk gerakan guna mengekspresikan kepentingan bersama dalam upayanya mempertahankan identitas dan kepentingan komunitas yang bersangkutan.

Dalam konteks global, Singapura memiliki sensitivitas keagamaan yang lebih tinggi di kawasan ASEAN. Isu terorisme global, Singapura dengan cepat merespon dan menjadi perhatian serius bagi pemerintah Singapura. Banyak tuduhan berasal dari Singapura bagi gerakan-gerakan Islam radikal di kawasan ASEAN termasuk Indonesia yang dianggap sebagai jaringan terorisme internasional.

\footnotetext{
${ }^{68}$ Lihat ibid., hal. 404.

${ }^{69}$ Lihat ibid., hal. 408.

${ }^{70}$ Lihat D.E. Smith, Religion and Political, hal. 136.
} 


\section{E. Penutup}

Sejarah Singapura awal diwarnai oleh kesimpangsiuran data yang menceritakan sejarah Singapura dan didasarkan pada legenda dan cerita-serita mitos yang berkembang. Sejak awal keberadaannya sampai terbentuknya negara-kota modern, Singapura selalu berada di pangkuan kekuasaan asing dengan melalui proses unik. Struktur sosial masyarakat Singapura yang multi rasial dengan mayoritas imigran Cina dan berkembang sedemikian pesat telah melahirkan kesadaran nasionalisme di tanah perantauan. Interaksi sosial politik yang didasarkan pada sentimen etnik dan agama telah mengkristal dengan pemisahan Singapura dari federasi Malaysia sebagai negara merdeka yang bertumpu pada perindustrian dan perdagangan.

Terakomodasinya kepentingan umat Islam paralel dengan seberapa jauh pertisipasi mereka dalam menentukan kebijakan politik penguasa. Pada masa awal kerajaan dan kesultanan, komunikasi politik lebih bersifat satu arah, rakyat hanya mengikuti apa yang menjadi keputusan raja atau sultan. Sementara pada masa penjajahan Inggris komunikasi politik lebih bersifat responsif penguasa terhadap tekanan-tekanan kepentingan umat Islam dari bawah. Terpenuhinya sebagian besar kepentingan umat Islam Singapura seiring dengan meningkatnya kesadaran umat akan pentingnya wadah formal untuk menampung aspirasi yang berkembang. Meskipun demikian, Islam ditempatkan pada kerangka gerakan yang mencurigakan.

\section{DAFTAR PUSTAKA}

Andaya, Barbara Waston dan Virginia Matheson, 1995, “Raja Ali Haj:Antara Pemikiran Islam dan Tradisi Melayu" dalam Alhikmah no, 4. Vol. vi. Bandung: Yayasan Muthahhari.

Anderson, J.N.D., 1994, Islamic Law in The Modern World. -New York: Newyork University Press.

Azra, Azyumardi, 1989, "Pendahuluan: Islam di Asia Tenggara" dalam Azyumardi Azra (ed), Perspektif Islam di Asia Tenggara. Jakarta: Yayasan Obor Indonesia.

Berg, L.W.C. Van den, 1996, Hadratulmaut dan Koloni Arab di Nusantara, terj. Rahayu Hidayat. Jakarta: INIS. 
Cady, john F., 1976, Southeast Asia Historical Development. New Delhi: McgrawHill, Inc.

Denveden, R. Von, 1987, “Melayu: Islam and Muliethnics Politics" dalam John LEsposito (ed.) Islam in Asia: Religion, Politics and Society. Oxford: Oxford University Press.

Esposito, John L, 1995, Ancaman Islam, Mitos atau Realitas? Terj. Abd Rahman dan Muis. Cet. II; Bandung: Mizan.

Guilhot, Claude, 1999, “Orang Kalang di Pulau Jawa: Juru-juru Angkut dan Pegadaian” dalam Henri Chamber Loin dan Hasan Ma'arif Ambari, Panggung Sejarah: Persembahan kepada Prof. Dr. Denys Lombard. Jakarta: Yayasan Obor Indonesia.

Hashim, Muhammad Yusuff, 1990, Kesultanan Melayu Melaka. Cet. II; Kuala Lumpur: Dewan Bahasa dan Pustaka.

Hooker,Virgina Matheson, 1991, Tuhfat al-Nafis: Sejarah Melayu Islam, terj. Ahmad Fauzi Basri Kualalumpur: Dewan Bahasa dan Pustaka.

Keldman, Melville W. dan Rudolph T Yeatman Jr, 1965, The Word university, Encyclopedia, vol. 10. USA: Wasington DC Pablishings.

Means, G, 1982, “Malaysia: Islam in a Plural Society" dalam C. Caldarela (ed.) Religion and Societies: Asia and Middle East. Boston: Mouton Press.

Meulen, D. Van Der \& H. Von Wissmann, 1969, Hadratmaut Some of Its Mysteries Unveited. Leyden: E.J. Brill. Ltd.

Naim, Abdullahi Ahmaed, al-,1994, Dekonsruksi Syari'ah. Yogyakarta:LKiS.

Pelinson, Cril Nortcote, 1976, "Singapura" dalam Encyclopaedia Britannica, vol. 20. USA: Encyclopaedia Britannica. Inc.

Rosenthal, Ervin I.J., 1965, Islam in the Modern Nation State. Cambridge: Cambridge University Press.

Smith, Donald Eugene, 1974, Religion, Politics, and Social Change in the Third World. Cet. III; USA: A Free Press Paperback. 
------,1970, Religion and Political Development. Boston: Little Brown \& Company.

-----,1966, South Asia, Politics and Religion. New York: Pricenton university Press.

Steinberg, David Joel, 1971, In Search of Southeast Asia. Singapura: Oxford University Press.

Sutrisno, Sulastin, 1983, Hikayat Hang Tuah: Analisa Struktur dan Fungsi. Yogyakarta: Gajah Mada University Press.

Tebba, Sudirman (ed.), 1993, Perkembangan Mutakhir Hukum Islam di Asia Tenggara.Bandung: Mizan.

Turnbull, C. Mary, 1980, A History of Singapore 1819-1975. Cet. III; Malaysia: Oxford University Press.

Vlekke, Bernard H.M., 1965, Nusantara, A History of Indonesia. Cet. VI; Nederland: W. Van Hoeve Ltd-The Hague.

Voll, John Obert, 1997, Poltik Islam, Kelangsungan dan Perubahan di Dunia Modern, terj. Ajat Sudrajat. Yogyakarta: Titian Ilahi Press.

Yinger, J. Milton, 1970, Scientific Study of Religion. New York: Macmillan Publishing. Inc. 